\title{
Avomaankurkkulajikkeita teollisuuden tarpeisiin
}

\author{
Terhi Suojala \\ MTT, kasvintuotannon tutkimus, Puutarhatuotanto, Toivonlinnantie 518, 21500 Piikkiö, \\ terhi.suojala@mtt.fi
}

\begin{abstract}
Johdanto
Vihannesten lajikevalinta on viljelyn perusta, sillä perintötekijät määrääväät, mihin hyvällä viljelytekniikalla on mahdollista päästä. Valittaessa lajikkeita viljelyyn pohjoisissa oloissa on tyydyttävä jalostajien ja maahantuojien antamiin tietoihin lajikkeiden ominaisuuksista ja menestymisestä, sillä vihannesten lajikekokeita ei ole maassamme järjestetty yli kymmeneen vuoteen yksittäisiä kokeita lukuunottamatta. Lajiketutkimusta pidetään kuitenkin alalla hyvin tarpeellisena, jotta päästäisiin kokeilusta järjestelmällisempään vertailuun. Elintarviketeollisuusliiton Vihannessäilyketeollisuusyhdistyksen taloudellisella tuella MTT on toteuttanut avomaankurkun lajikekokeen kahtena viime kasvukautena.

Avomaankurkkua viljellään Suomessa noin 400 hehtaarin alalla, josta $80 \%$ on sopimustuotantoa säilykkeitä valmistavalle teollisuudelle (Maa- ja metsätalousministeriön tietopalvelukeskus 2003). Viljelyn ongelmia ovat olleet vuotuiset satovaihtelut ja hedelmien laadussa esiintyvät puutteet erityisesti säilöntäprosessin kannalta. Kurkkulajikkeelle asetetaan lukuisia vaatimuksia: sadon tulee olla riittävän suuri, valmistua aikaisin ja laadun tulee säilyä tasaisena koko satokauden ajan. Kasvuston tulee olla helposti poimittavissa ja terve. Hedelmien rakenteen on oltava riittävän kiinteä, eikä kuori saa olla sitkeä.

Tämän tutkimuksen tavoitteena oli selvittää eri avomaankurkkulajikkeiden viljelyvarmuus, kasvuominaisuudet, satoisuus ja sadon laatu Suomen oloissa. Lisäksi yhteistyökumppanit säilyketeollisuudesta arvioivat lajikkeiden soveltuvuutta omiin prosesseihinsa.
\end{abstract}

\section{Aineisto ja menetelmät}

Lajikekoe järjestettiin vuosina 2002 ja 2003 MTT puutarhatuotannossa Piikkiössä. 11-12 lajiketta valittiin kokeeseen neljän jalostajan antamien ehdotusten ja kotimaisten asiantuntijoiden kommenttien mukaan, ja osa niistä oli vielä nimeämättömiä numerolajikkeita (Taulukko 1). Osa lajikkeista vaihdettiin ensimmäisen koevuoden jälkeen, mutta kuusi lajiketta oli samoja molempien vuosien kokeissa. Vertailulajikkeena pidettiin 'Carinea', jota on käytetty MTT:n muissa kurkkukokeissa jo useana vuonna ja jota viljellään yleisesti tiloilla. Koe järjestettiin satunnaistettujen täydellisten lohkojen kokeena, jossa oli neljä lohkoa. Koeruutu oli mitoiltaan 1,5 metriä x 7 metriä. Maalaji oli vuonna 2002 multava hietamoreeni ja vuonna 2003 runsasmultainen hietasavi.

Kurkun taimia esikasvatettiin kasvihuoneessa runsaat kaksi viikkoa ja istutettiin avomaalle parin päivän karaisun jälkeen kesäkuun 3. päivänä vuonna 2002 ja kesäkuun 5.-6. päivänä vuonna 2003. Vuonna 2002 kahden lajikkeen siemenet saatiin viisi vuorokautta muiden lajikkeiden kylvön jälkeen, joten niiden taimet olivat istutettaessa viisi vuorokautta nuorempia. Verrannelajike 'Carine' kylvettiin siksi molempina kylvöajankohtina, jotta kaikkia lajikkeita oli mahdollista verrata siihen. Taimet istutettiin muovilla katettuun penkkiin, johon oli sijoitettu tihkuletku kastelua varten. Lannoitus koostui ennen muovin levittämistä annetusta peruslannoituksesta ja tihkuletkujen kautta annetusta kastelulannoituksesta, joka aloitettiin hieman ennen satokauden alkua. Kastelutarvetta seurattiin mittaamalla maan kosteutta $20 \mathrm{ja} 40 \mathrm{~cm}: \mathrm{n}$ syvyyksiin asetetuilla tensiometreillä.

Lajikkeista havainnoitiin vegetatiivista kasvua kolme kertaa kasvukaudella laskemalla lehtien, sivuversojen ja kukkien määrä kahdesta taimesta ruutua kohti. Sato poimittiin kaksi kertaa viikossa. Vuonna 2002 satokausi alkoi 11.7 ja päättyi 16.9., vuonna 2003 sadonkorjuuseen päästiin 10.7. ja se päättyi 1.9. yöhallojen vioitettua kasvustoa. Sato lajiteltiin kolmeen kokoluokkaan, lisäksi poistettiin virheelliset (lähinnä epämuotoiset) kurkut. Kurkkujen ulkonäköä arvioitiin silmävaraisesti. Lisäksi mitattiin molempina kesinä kahdesti kurkkujen kiinteyttä Lloyd-aineenkoetuslaitteella. Mittauksessa työnnettiin halkaisijaltaan 4,8 mm:n vahvuinen puikko hedelmän sisään vakionopeudella ja mitattiin etenemiseen tarvittu voima.

\section{Tulokset ja tulosten tarkastelu}

Lajikkeiden kasvustot olivat pellolla yllättävän samannäköisiä, eikä niitä ollut helppo erottaa toisistaan. Myöskin numeerisissa kasvuhavainnoissa erot jäivät yllättävän pieniksi: lehtien lukumäärässä ja vuonna 2002 myös sivuversojen määrissä tainta kohti oli pieniä eroja, mutta erot eivät olleet aivan yhdenmukaisia 
molempina vuosina niissäkään lajikkeissa, jotka olivat mukana molemmissa kokeissa. Taudeista ei kokeissa ollut harmia, joten lajikkeiden taudinkestävyydestä ei saatu tietoa.

Satomäärissä lajike-erot olivat suuremmat ensimmäisen vuoden kokeessa. Koko kauden aikaisessa sadossa erottuivat vuonna 2002 Bejon jalostamat lajikkeet 'Adam', 'B2580' ja 'B2590', jotka tuottivat muita lajikkeita korkeamman sadon. Suurimmat erot satomäärissä syntyivät satokauden alussa, jolloin nämä lajikkeet olivat selvästi satoisampia kuin verrannelajike 'Carine'. Pääsadon aikana elokuussa lajikkeiden välillä ei ollut mainittavia satoeroja. Loppusadossa saman jalostajan lajike 'Celine' oli verrannetta satoisampi.

Toisena koevuonna koko kesän aikaisessa sadossa ei ollut lainkaan tilastollisesti merkitseviä eroja. Tuottoisimman lajikkeen ('B2590') sato oli noin 13 tonnia hehtaarilla suurempi kuin heikoimman lajikkeen ('RS 1939') sato, mutta ero ei ollut tilastollisesti merkitsevä. Tarkasteltaessa satotuloksia satokauden eri osissa ilmeni joitakin tilastollisesti merkitseviä eroja. Satokauden alkukolmanneksella tuottoisimpia olivat 'B2590' ja 'Etude', keskivaiheilla eniten satoa tuottivat 'RS 1989' ja 'RZ 12-17' ja loppuvaiheessa erottui lähinnä 'RS 1939', jonka tuottokyky hiipui muita aikaisemmin.

Sadon lajittelu eri koko- ja laatuluokkiin antoi hieman lisää tietoa lajikeominaisuuksista. Kun satoa poimittiin kaksi kertaa viikossa, osa hedelmistä ehti kasvaa yli halutun kokoluokan eli halkaisijaltaan yli 45 mm:n kokoisiksi. Vuonna 2002 ylisuuria kurkkuja oli eniten lajikkeiden 'Opus', 'Etude' ja 'RZ 12-18' sadossa. Seuraavan vuoden kokeessa ylisuuria hedelmiä oli jälleen eniten RZ 12-18 -lajikkeessa ja verrannetta enemmän myös Nun $4011 \mathrm{Pu}$-lajikkeessa. Epämuotoisia kurkkuja oli vuoden 2002 sadossa melko paljon eli 8-12 \% kokonaispainosta. Lajike-erot virheellisten kurkkujen määrissä olivat suurimmat satokauden lopulla. Tällöin lajikkeissa 'Adam', 'Profi', 'Servus' ja 'Celine' oli eniten epämuotoisia hedelmiä. Vuoden 2003 kokeessa virheellisiä kurkkuja oli vain 2-5\% sadosta, ja lajikkeissa 'RZ 12-18', 'RS 1989', 'Celine' ja 'RS 1939' niitä oli hieman muita enemmän.

Hedelmien kiinteysmittauksissa erottuivat vuonna 2002 rakenteeltaan muita pehmeämpinä lähinnä Bejon jalostamat lajikkeet 'Adam', 'B2580' ja 'B2590'. Näistä oli seuraavan vuoden kokeessa mukana ainoastaan 'B2590', joka oli jälleen lajikkeista pehmein. Molempien vuosien mittauksissa kiinteät hedelmät olivat mm. lajikkeilla 'Servus', 'Celine' ja 'RZ 12-18', ja vuoden 2003 kokeessa myös lajikkeilla 'Capra' ja 'Nun $4011 \mathrm{Pu}$ '.

\section{Johtopäätökset}

Kahden vuoden lajikekokeissa on saatu käsitystä jalostajien arvioiden mukaan Suomen oloihin soveltuvista avomaankurkkulajikkeista. Tulosten mukaan kaikki lajikkeet soveltuvat täällä viljeltäviksi, mutta hyvää satoa ja laatua tavoiteltaessa oikean lajikkeen valinta on tarkka tehtävä. Puolet kokeissa olleista lajikkeista oli samoja molempina vuosina, mutta kaikilta ominaisuuksiltaan ne eivät käyttäytyneet samalla tavalla eri vuosina. Näin ollen lajikkeiden ominaisuuksia on tarpeen selvittää vähintään kahtena - kolmena vuonna luotettavien johtopäätösten saamiseksi, sillä sääolot ja kasvupaikka vaikuttavat tuloksiin.

Satoerot lajikkeiden välillä olivat odotettua pienemmät. Erityisesti vuonna 2002, jolloin satokausi alkoi hieman myöhässä kasvustoa vaivanneen fysiologisen vioituksen takia, lajikkeet, joiden sato alkoi aikaisin, tuottivat myös suurimman kokonaissadon. Sama lajike oli satoisin myös seuraavana vuonna, jolloin lajike-erot olivat pienemmät. Asiantuntijoiden kokemusten mukaan sadon aikaisuus ja toivottu hedelmän kiinteä rakenne eivät kuitenkaan yleensä yhdisty samaan lajikkeeseen. Näin ilmeni myös tässä tutkimuksessa: aikaiset ja satoisat lajikkeet tuottivat rakenteeltaan pehmeitä kurkkuja, jotka eivät sovi säilöntään. Hyvää laatua tavoiteltaessa suuri sato ei siis voi olla ensisijainen valintakriteeri.

Avomaankurkun lajikekokeita jatketaan vielä ensi kesänä. Kolmen vuoden koetulosten perusteella saataneen käsitys lajikkeiden viljelyvarmuudesta sekä sadon määrästä ja laadusta. Muita heikompi sato, hedelmien pehmeys tai lajikkeen alttius muodostaa epämuotoisia hedelmiä ovat tekijöitä, joilla melko tasalaatuisten lajikkeiden joukosta karsitaan heikoimmat pois.

Kurkun lajikekoe on osoittanut, että vihannesten lajiketutkimusta voidaan tehdä hyvässä yhteistyössä teollisuuden kanssa. Lajikkeiden vertailu samalla paikalla kenttäkokeiden periaatteita noudattaen varmentaa tulosta, olipa se sitten selvien lajike-erojen löytyminen tai lajikkeiden tasavahvuuden todentaminen. Johtopäätösten tekeminen eri kasvupaikoilta, erilaisista viljelykäytännöistä tai silmävaraisista arvioista saatujen kokemusten perusteella jää kevyeksi, vaikka siihen joudutaan nykytilanteessa usein turvautumaan lajikevalintaa tehtäessä.

Lajikekokeiden päätarkoituksen - lajikkeiden ominaisuuksien tunnistamisen - ohella samoja kokeita voi hyödyntää muihin tutkimustarkoituksiin. Esimerkkinä tästä on kurkun hedelmien kiinteysmittaukset, joita käytettiin tässä lajikkeiden laatututkimuksiin. Hyvien kokemusten innostamana samaa menetelmää on 
nyt hyödynnetty muissa avomaankurkkuun liittyvissä tutkimuksissa. Syntynyttä tulosmateriaalia on mahdollista hyödyntää mittausmenetelmän kehittämisessä ja hedelmän laatuun vaikuttavien tekijöiden tutkimuksessa.

\section{Kirjallisuus}

Maa- ja metsätalousministeriön tietopalvelukeskus. 2003. Puutarhayritysrekisteri 2002. Helsinki.

Taulukko 1. Avomaankurkun lajikekokeissa vuosina 2002 ja 2003 tutkitut lajikkeet.

\begin{tabular}{|c|c|c|c|c|c|}
\hline Vuosi & Lajike & Jalostaja & Vuosi & Lajike & Jalostaja \\
\hline \multirow[t]{12}{*}{2002} & Carine $^{1)}$ & Royal Sluis & 2003 & Carine & Royal Sluis \\
\hline & Celine $^{2)}$ & Royal Sluis & & Celine & Royal Sluis \\
\hline & Clementine $^{2)}$ & Royal Sluis & & RS 1939 & Royal Sluis \\
\hline & Opus & Rijk Zwaan & & RS 1989 & Royal Sluis \\
\hline & Etude & Rijk Zwaan & & Etude & Rijk Zwaan \\
\hline & RZ 12-18 & Rijk Zwaan & & RZ 12-17 & Rijk Zwaan \\
\hline & Adam & Bejo Zaden & & RZ 12-18 & Rijk Zwaan \\
\hline & B2580 & Bejo Zaden & & RZ 12-21 & Rijk Zwaan \\
\hline & B2590 & Bejo Zaden & & B2590 & Bejo Zaden \\
\hline & Profi & Nunhems Zaden & & Servus & Nunhems Zaden \\
\hline & Servus & Nunhems Zaden & & Capra & Nunhems Zaden \\
\hline & & & & Nun $4011 \mathrm{Pu}$ & Nunhems Zaden \\
\hline
\end{tabular}

\footnotetext{
${ }^{1)}$ Mukana sekä aikaisemmassa että myöhemmässä kylvöerässä.

${ }^{2)}$ Kylvetty 5 vrk myöhemmin kuin muut lajikkeet, koska siemenet saapuivat myöhässä.
} 